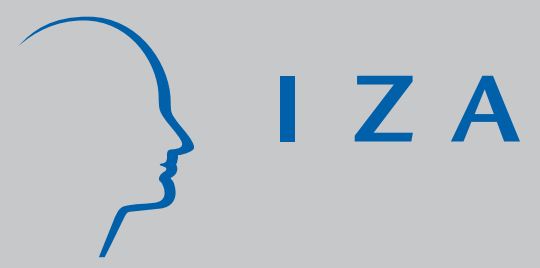

IZA DP No. 51

Does Training Generally Work?

The Returns to In-Company Training

Alan Barrett

Philip J . O'Connell

August 1999 


\title{
Does Training Generally Work? The Returns to In-Company Training
}

\author{
Alan Barrett \\ Economic and Social Research Institute, Dublin \\ Philip J. O'Connell \\ Economic and Social Research Institute, Dublin
}

\author{
Discussion Paper No. 51 \\ August 1999
}

\author{
IZA \\ P.O. Box 7240 \\ D-53072 Bonn \\ Germany \\ Tel.: +49-228-3894-0 \\ Fax: +49-228-3894-210 \\ Email: iza@iza.org
}

This Discussion Paper is issued within the framework of IZA's research area General Labor Economics. Any opinions expressed here are those of the author(s) and not those of the institute. Research disseminated by IZA may include views on policy, but the institute itself takes no institutional policy positions.

The Institute for the Study of Labor (IZA) in Bonn is a local and virtual international research center and a place of communication between science, politics and business. IZA is an independent, nonprofit limited liability company (Gesellschaft mit beschränkter Haftung) supported by the Deutsche Post AG. The center is associated with the University of Bonn and offers a stimulating research environment through its research networks, research support, and visitors and doctoral programs. IZA engages in (i) original and internationally competitive research in all fields of labor economics, (ii) development of policy concepts, and (iii) dissemination of research results and concepts to the interested public. The current research program deals with (1) mobility and flexibility of labor markets, (2) internationalization of labor markets and European integration, (3) the welfare state and labor markets, (4) labor markets in transition, (5) the future of work, and (6) general labor economics.

IZA Discussion Papers often represent preliminary work and are circulated to encourage discussion. Citation of such a paper should account for its provisional character. 


\section{ABSTRACT}

\section{Does Training Generally Work? The Returns to In-Company Training}

This paper applies the familiar theoretical distinction between general and specific training to the empirical task of estimating the returns to in-company training. Using a firm-level dataset which distinguishes between general and specific training, we test for the relative effects of the two types of training on productivity growth. We find that although general training has a statistically positive effect on productivity growth, no such effect is observable for specific training. This positive effect of general training remains when we control for factors such as changes in work organisation and corporate re-structuring, firm size and the initial level of human capital in the enterprise. Moreover, the impact of general training varies positively with the level of capital investment.

JEL Classification: J24

Keywords: General training, specific training, productivity growth

Philip O'Connell

Economic and Social Research Institute

4 Burlington Road

Dublin 4

Ireland

Tel.: 353-1 6671525

Fax: 353-1 6686231

Email: Philip@esri.ie

\footnotetext{
We would like to acknowledge the financial support of FÁS (Irish Training and Employment Authority), CEDEFOP (European Centre for the Development of Vocational Training) and IBEC (Irish Business and Employers Confederation). We would also like to acknowledge the helpful comments of Ann Bartel in designing the questionnaire and of John Bradley, Denis Conniffe, Daniel Hamermesh, Harry Holzer and Brian Nolan.
} 
In recent years a number of papers have appeared which seek to measure the effect of employer-provided training on productivity using firm-level data (Holzer et al, 1993, Bartel 1994, Black and Lynch, 1996). Previously, such exercises were constrained by the lack of appropriate data. With the growth in firm-level data and the relaxation of this constraint, we are beginning to develop a deeper knowledge of the link between training provided by the employer and productivity.

In this paper we add to this area of research by drawing on a new data set which allows us to analyse a particularly interesting dimension of the effect of employer-provided training. The data used were specifically designed to collect detailed information on firms' training practices, including a measure of days spent on specific and general training, following Becker's (1975) familiar distinction. Although the distinction between these types of training has been well developed in the theoretical literature, empirical studies which draw on this distinction are extremely rare $^{1}$. Also included is information on output, capital and employment at two points in time. This allows us to estimate the impact of general and specific training on productivity growth. In addition, a range of variables indicating changes in corporate structure, organisational and personnel policies are also included. Hence, in estimating the effects of general and specific training, we are able to control for the effects such changes might have on productivity growth. In sum, the data allow the paper to make both a novel contribution to the measurement of the impact of training and an important addition to the limited empirical work on general versus specific training.

\footnotetext{
${ }^{1}$ One recent exception is Loewenstein and Spletzer (forthcoming).
} 


\section{Literature Review}

A number of studies have looked at the effect of employer-provided training by analysing the impact on wages using data on employees (e.g. Booth, 1991; Lynch, 1992). Other studies have adopted a case study approach and have looked at the relationship between training and productivity in a limited number of enterprises, such as the work of the National Institute for Economic and Social Research (NIESR, 1990). Our approach is to use a firmlevel dataset in a regression framework to estimate the impact of training on productivity. As such, we will restrict this brief review of the literature to studies of this type.

One of the earliest such studies is Holzer et al (1993). The study arose out of a grant programme run by the State of Michigan, through which grants were made available to manufacturing companies for the financing of training. By surveying companies which had applied for grants, a data set was generated with information on training inputs and companies' outputs. In addition, as they had information on the companies over a number of years it was possible to look at how productivity changes across firms are related to changes in training, thereby overcoming the familiar problem of time-invariant unobserved heterogeneity. Working with samples of between 171 and 250 firms, they find evidence of a direct link between training and productivity. Bartel (1994) again looked at the link between training and productivity using around 150 firms from another survey of employers, the Columbia Business School survey. Like Holzer et al, she also finds a positive effect of training on productivity. 
This employer-based approach to estimating the training/productivity relationship has recently been advanced in a series of papers by Lisa Lynch and Sandra Black (Lynch and Black 1995, Black and Lynch, 1996 and Black and Lynch, 1997). Their advances have been facilitated by a new data set which, as the authors put it, "was designed to overcome some of the limitations of previous studies and collect more precise data on human-capital inputs and establishment inputs" (Black and Lynch, 1996, p263).

The authors use the data for a number of purposes. For current purposes, the first results of interest are found in the 1995 paper $^{2}$. Production functions are estimated for the manufacturing and non-manufacturing sectors in which dimensions of training are included along with the more usual arguments in production functions such as capital and labour. The results on training are interesting; the number of workers trained is not found to have a significant effect on productivity but this masks the effects of different dimensions of training, which do matter. In manufacturing, the higher the proportion of training that is off-the-job, the higher is productivity. Similarly, in non-manufacturing the type of training matters for productivity; in particular, training in computer skills increase productivity.

As the results presented in the 1995 and 1996 papers of Black and Lynch are based on data from a single year, they suffer from the problem of unobserved heterogeneity, mentioned above ${ }^{3}$. In the 1997 paper, they attempt to overcome this by supplementing the original data with data from the Longitudinal Research Database (LRD) of the United States

\footnotetext{
2 The same results are found in the 1996 paper which is a published version of a section of the 1995 working paper.
} 
Bureau of the Census. The authors were able to match the companies with records in the LRD and thereby create a dataset with information over time. In re-estimating their earlier work, they now find no effect of training on productivity; however, they maintain that this was probably because the information on training was too weak for its effect to be captured in the extended estimation framework. What does emerge from this study is the interesting effects of workplace practices on productivity. In particular, greater involvement of workers in decision making and the use of performance related pay are seen to generate higher productivity relative to the more traditional labour/management relations. ${ }^{4}$

\section{General and Specific Training}

As noted in the Introduction, our task in this paper is to estimate the effects of general and specific training on productivity growth. In this section, we discuss the concepts and why these forms of training may differ in their impacts.

Becker (1993) defines general training as being the type of training which raises productivity by equal amounts in the firm where it was provided and in other firms. In contrast, specific training only raises productivity in the firm where it was provided. Under certain conditions, these definitions imply that firms will not pay for general training. As an individual's productivity is raised in other firms, alternative wage offers will increase. If the employer who provided the general training is to retain the employee, the alternative wage offers would have to be met and hence no return to the training investment can be captured. The

\footnotetext{
${ }^{3}$ This is acknowledged by the authors; see p266 of the 1996 paper.

${ }^{4}$ The importance of workplace practices arises again in the paper by Ichniowski et al (1995).
} 
employee will bear all the costs of general training, possibly through a reduced wage during the training period. As specific training does not lead to increased productivity and higher wage offers elsewhere, the firm will be prepared to share the costs of specific training.

An additional implication of these definitions arises if there is a constraint on the employer's ability to offer an employee a lower wage while training. If, for example, a wage is attached to a particular job through an agreement with a union, the firm will not be able to shift the costs of training onto the employee. Such a situation leads to a market failure in the provision of training The failure is more likely to relate to the provision of general training, given the need to shift all the costs of training, as opposed to a proportion of the costs.

Since Becker introduced the distinction, some doubts have been raised about the implications for who funds training. Bishop and Kang (1996) point out that strong predictions of Becker's theory require that (i) labour markets are competitive, (ii) workers can finance general on-the-job training investments by borrowing at a fixed interest rate and (iii) technically general skills can be cheaply signalled to other potential employers. They then develop a model in which these assumptions are relaxed and predictions emerge in which employers do share the costs of general training. Their empirical analysis fails to show greater effects of general training on wage growth than productivity growth, as would be predicted by the rigid application of Becker's theory. Similarly, Loewenstein and Spletzer (forthcoming) do not find any systematic difference in the wage returns to general and specific training, which is consistent with employers sharing the costs and returns to general and specific training. They also find in their data that most of the training provided by 
employers is general in nature, which runs counter to the prediction of a lower provision of general training when shifting the full cost to employees is not possible.

This recent work has forced us to re-think our understanding of the implications of the distinction between general and specific training. As part of this re-evaluation, we want to focus here on another dimension of the distinction, namely, whether the two types of training will have different impacts on productivity growth. As noted above, Lynch and Black (1995) have shown empirically that, in manufacturing, off-the-job training has a greater impact on productivity than on-the-job training. Below, we estimate if such differences hold for general and specific training but here we will outline a hypothesis as to why a difference might exist.

In order to generate a hypothesis, it is useful to think about training as being a production activity, the output of which is higher human capital. However, rather than seeing the output as being produced by a single input, such as the employers expenditure, we can think of the training output as being produced by the joint efforts of the employer and the employee. While the employer can provide the classes or the demonstrations, the extent to which such activities are turned into human capital depends on the extent to which the employee devotes effort to learning new skills and to applying the new skills. Once training is viewed in this manner, the issue arises of whether employees have different incentives to exert effort when undertaking different forms of training. ${ }^{5}$

\footnotetext{
${ }^{5}$ While the issue of effort at work has been considered in, for example, the efficiency wage literature (Shapiro and Stiglitz, 1984), we are not aware of any analyses of effort in training.
} 
The incentive for the employees to devote effort in training arises from the benefits which the training provides them. In the case of both general and specific training, the increased productivity to which training leads will also lead to increased wages with the current employer. However, given that general training also raises productivity and wages elsewhere, it provides an additional benefit which can be viewed as an insurance policy. Should the employee be laid off or wish to leave the current employer, the general training acquired can be used elsewhere while specific training cannot. In this way, as long as there is a positive probability of separation from the current employer, even a risk neutral employee will gain a greater expected benefit from general training. As such, employees are more likely to devote greater effort to general training.

\section{Research Design and the Data Set}

The analysis presented below draws on a data set that was generated in two waves. The first wave is a survey of enterprises conducted in Ireland in 1993 and reported in Fox (1995). The survey was part of an effort funded by the European Union to establish, for the first time, comparable data within the EU on the nature and extent of training in companies ${ }^{6}$. For each of the countries involved, broadly standardised questionnaires were designed to collect detailed information on the training practices.

In the case of Ireland, a nationally representative sample of 1,000 enterprises were randomly selected. The survey covered companies employing more than 10 people in

\footnotetext{
${ }^{6}$ For a full description of the EU survey, see Eurostat (1996).
} 
manufacturing, construction and private services. Interviewers were sent out to the enterprises and typically dealt with individuals responsible for training provision within the enterprise; in the case of small firms, this individual may also have been the chief executive. The focus of the questionnaire was on continuing vocational training, rather than initial training, and so apprentices and trainees are excluded in the responses ${ }^{7}$.

A total of 654 useable returns were obtained from this survey. The information obtained includes items such as the activity of each company, the number of employees and the distribution of employees in the enterprise across five broad occupational categories. As regards training, a range of questions were asked about different aspects. The training managers were asked if certain types of training were provided such as training in the work situation, conferences workshops or seminars, job rotations and exchanges and selflearning. They were also asked how many employees received training of whatever nature and how much was spent on training, including an estimate of the cost of time foregone by employees while training. Questions were also asked about how many days of training were provided to employees. Our measure of general and specific training is derived from this series of questions: the training managers were asked to provide a break-down of the total number of days of training into: (a) seven categories of "general training"; (b) four categories of training "specific to company's activity"; and (c) a residual class of "other training" ${ }^{8}$. We would argue that relying on training managers to apply the general/specific distinction to their

\footnotetext{
7 Trainees and apprentices were defined in the instructions as "employees whose wages/salaries are determined by the fact that they are being trained or are studying for a recognised qualification relevant to their trade or profession".

${ }^{8}$ In the instructions which accompanied the questionnaire respondents were asked to clasify as 'general' training which provided "broad skills and knowledge"; training which was "directly related to the operation of the company" was to be classified as 'specific'.
} 
own training activities represents a more satisfactory way of capturing this theoretically important distinction than reliance on an ex-post coding of data, based, for example, on information about the content or location of training.

Although the 1993 survey contained much information on training activities, it did not contain information which would allow us to estimate the effect of training on productivity growth. In order to generate the information required, we conducted a follow-up survey of the 654 companies in April and May of 1997. This survey was initially carried out through postal questionnaires and posted reminders, but non-respondents were eventually phoned. Given that the sample which we were re-surveying was quite small, we sought to maximise the response rate by minimising the amount of information sought. The main pieces of information sought were as follows: output in 1993 and 1995, as measured by the sales figures from the end of year accounts in each period (this in turn would be used to calculate productivity in the two periods); the value of fixed assets at the same two points in time, again from the end of year accounts; the size of the workforce, in 1993 and 1995 . We also asked if there had been changes in personnel policy, corporate organisation and corporate structure between 1993 and 1995; as such changes could have impacted upon productivity growth, we thought it important to be able to control for them.

Excluding 12 public authorities, the original survey consisted of 642 enterprises. Eliminating responses with incomplete data reduced the number of cases from the follow-up survey to 215; hence the response rate based on the 642 enterprises was 33.5 percent. In order to check for bias in the response we compared the second-wave cases with the first-wave and 
found that the distribution of companies by sector and size category was very similar in both surveys. We also found that the mean values of the training measures were very similar in the two surveys, and not statistically different. Some descriptive statistics on the firms who responded to the second survey can be found in Table 1 below.

Before proceeding with the analysis, it is worth saying a few words on the Irish economy, by way of establishing whether lessons learned from Irish data can be applied elsewhere. Ireland has been a member of the European Union since the early 1970s, one of the effects of which has been a substantial opening of the economy. This openness can be seen in the level of exports relative to national income; in 1995 (the year to which our second survey relates), its exports of goods and services were valued at 87 percent of GNP. The openness can also seen in the level of foreign ownership in the Irish economy; again in 1995, in terms of numbers employed, just under half of manufacturing activity in Ireland is in enterprises owned by non-Irish companies. Of the foreign owned, just over half is U.S. owned. Such levels of openness, along with the high growth rates of recent years (estimated to be around 8 percent in 1998), suggest that Ireland is now a modern economy, well integrated into the economy of the EU and beyond. While it is likely that the scale of enterprises is smaller in Ireland than in the U.S., it is interesting to note that the median size of the enterprises studied here (60 employees) is identical to the mean in the Holzer et al (1993) study mentioned above. Finally, in an international comparison of the data from the EU survey discussed above, the proportion of enterprises in Ireland providing training was similar to those of Germany, France and the U.K; hence, training provision in Ireland appears to be similar to that in these other developed economies (Schömann, 1998). 


\section{The Estimation Framework}

The framework on which our estimation is based follows Bartel (1994) and assumes that the relationship between output and inputs at the company level has a standard Cobb-Douglas structure. $^{9}$ The production function is shown in Eq. 1 below. Output is a function of two inputs, capital (K) and 'effective labour' (EL), the latter consisting of the amount of labour services employed by the company.

$$
\mathrm{Q}=\mathrm{AK} \mathrm{K}^{\beta} L^{\gamma}
$$

where $\beta$ and $\gamma$ are numbers greater than zero, as is A.

Effective labour consists of the amount of labour employed (RL, or reported labour) and the stock of training that the workforce have received, its human capital $(\mathrm{H})$. Human capital thus refers to the accumulated stock of skills and competencies of the workforce; the training provided to employees in any year can thus be thought of as a "flow" variable, that is the amount that is added to the stock over a period of time. The relationship between effective labour (EL), reported labour (RL) and human capital $(\mathrm{H})$ is as follows:

$$
\mathrm{EL}=\mathrm{RL}(1+\lambda \mathrm{H})
$$

\footnotetext{
${ }^{9}$ Black and Lynch $(1996,1997)$ also use a Cobb-Douglas production function in their estimation.
} 
According to Eq. 2, if human capital stock $(\mathrm{H})$ was equal to zero, effective labour (EL) and reported labour (RL) would be the same. However, as $\lambda$ is a number greater than zero, if the stock of human capital is greater than zero, then effective labour is greater than reported labour.

Substituting Eq. 2 into Eq.1 , dividing through by reported labour (RL) and taking the logarithm of both sides we arrive at Eq. (3) which is a model of productivity, estimable using linear techniques:

$$
\ln (\mathrm{Q} / \mathrm{RL})=\ln \mathrm{A}+\beta \ln \mathrm{K}+(\gamma-1) \ln \mathrm{RL}+\gamma \lambda \mathrm{H}+\varepsilon^{10}
$$

As the estimation of Eq. 3 could produce a biased estimate of the effect of training on productivity due to unobserved heterogeneity, we difference Eq. 3 producing the following which is the equation we estimate:

$$
\begin{aligned}
& \ln \left(\mathrm{Q}_{\mathrm{t}} / \mathrm{RL}_{\mathrm{t}}\right)-\ln \left(\mathrm{Q}_{\mathrm{t}-1} / \mathrm{RL}_{\mathrm{t}-1}\right)=\beta\left(\ln \mathrm{K}_{\mathrm{t}}-\ln \mathrm{K}_{\mathrm{t}-1}\right) \\
& +(\gamma-1)\left(\operatorname{lnRL} L_{t}-\operatorname{lnRL} L_{t-1}\right)+\gamma \lambda\left(\mathrm{H}_{\mathrm{t}}-\mathrm{H}_{\mathrm{t}-1}\right)+\varepsilon_{\mathrm{t}}-\varepsilon_{\mathrm{t}-1}
\end{aligned}
$$

This equation relates changes in productivity to a range of variables, including the change in the human capital stock; $\left(\mathrm{H}_{\mathrm{t}}-\mathrm{H}_{\mathrm{t}-1}\right)$ is represented in the estimations reported below by the training provided by the companies in 1993. Equation (4) encapsulates the core concern in

\footnotetext{
${ }^{10}$ Although RL appears on both sides of the equation, it is valid to estimate how productivity responds to changes in labour inputs. This done by Bartel (1994). In addition, estimations in which the dependent variable is a function of an independent variable can be found in studies of macroeconomic convergence and systems of consumer demand.
} 
this study which, in essence, investigates whether training provided during 1993 brought about productivity growth between 1993 and 1995. The approach implies that we are estimating how the level of training in 1993 affected the change in productivity between 1993 and 1995. We believe this to be the correct approach and to be conceptually preferable to seeing how a change in training may be related to a change in productivity. To see why, consider two firms, one which initially provides no training and then increases its training input to 10 units of training per employee. Another firm provides 100 units of training per employee every year. As the latter firm is adding more to human capital, even though it has not increased its flow of training, we would expect it to experience the bigger growth in productivity in years subsequent years. Relating changes in training to changes in productivity would not provide an insight into the relationship of interest ${ }^{11}$.

\section{Results}

Before presenting the results of our estimation of Eq. 4, we will present some descriptive statistics on our sample of firms. These are contained in Table 1. It should be noted that our sample included some firms who had not undertaken any training in 1993.

Productivity at each point in time is measured as output divided by total employment; on average between 1993 and 1995, the sample reported productivity growth of 3.4 percent $^{12}$. The training variables require some explanation so we will provide this here. The first training

\footnotetext{
${ }^{11}$ Bishop and Kang (1996) also adopt this level/change approach.

${ }^{12}$ Output is measured as sales in the accounting years 1993 and 1995; again, this is similar to the measure used by Black and Lynch $(1996,1997)$. An effort was made in the follow-up survey to collect
} 
variable, trainees/employees, is simply the proportion of employees who received some amount of training in 1993. The fourth training variable is the number of days of training per employee. The seventh training variable is training expenditure as a proportion of expenditure on pay.

In order to produce variables that reflect the relative amounts of training that is general or specific in nature, we draw on the survey questions regarding the number of days spent on general and specific training discussed above. For each company we can calculate what proportion of total training days were general or specific in nature, i.e. general training days (or specific training days) divided by total training days. We then multiply these two ratios by the first, fourth and seventh training variables in Table 1 thus producing the values of the general and specific training variables shown ${ }^{13}$.

Investment was calculated by subtracting the value of fixed assets in 1993 from that in 1995 . Our corporate change variables are derived from a series of questions asking whether each of a series of policies had been implemented between 1993 and 1995. The questions relating to personnel policies included Performance Related Pay, Productivity Related Bonus Schemes, Performance Appraisal, Team Working and 'Other' personnel policies. Corporate innovation policies included Total Quality Management, World Class Manufacturing, Continuous Improvement/Kaizen, Business Process Re-engineering, Change Management, Benchmarking and 'other' high performance work systems. In order to

information on value added across firms but the information turned out to be too weak to be used in the estimations. 
impose a manageable structure on these variables, we conducted a factor analysis of the entire set of dichotomous variables relating to the implementation of personnel and innovation policies over the relevant period. The factor analysis identified two distinct factors relating to personnel policies and corporate innovation. Reliability analysis suggested that we could generate better scales by dropping the 'other' categories from the two scales these yielded a six-item Innovation scale with a Cronbach's alpha=.70 and a four-item Personnel policy scale with an alpha of .56. The Personnel Policies and Corporate Innovation scales were then created by simply adding the dichotomous scores of each of the constitutive items, yielding scales with means of .4 and .6 respectively.

Table 1 also includes summary information on average labour $\operatorname{cost}^{14}$ in the enterprises in 1993 and on the size of the enterprises, in terms of number of employees, again in 1993. In order to provide a further insight into the dataset, a correlation matrix is provided in the Appendix.

In Table 2, we present the results of estimating Eq. 4 using three measures of training, without distinguishing between general and specific training. Given our primary interest in the effect of training, the results on this variable are most noteworthy. In two of the three models, training is seen to have a positive and significant effect on productivity growth. That significance is not seen in the expenditure version may be related to measurement error; Fox (1995) in his write-up on the original survey comments that this measure of training

\footnotetext{
13 It will be seen that the sum of the general and specific training variables is less than the corresponding composite training variables in each case. This is because of the residual training category of 'other training'.

${ }^{14}$ Labour cost is made up of wages/salaries, bonuses, social security and pension contributions.
} 
produced the most uncertain responses. Hence, we can say that we are finding the same effect as Holzer et al (1993) and Bartel (1994). The coefficients of both investment and change in employment are measured with statistical precision, as can be seen from their tvalues across all specifications, and have plausible signs. Extra capital should increase labour productivity so the positive investment coefficient is as expected. Employment increases would be expected to reduce productivity through a diminishing returns effect and/or through lower productivity of new hires, so the negative coefficient on employment change is also as expected. In general, the sectors do not seem to differ from the reference category ("other sectors") in terms of productivity growth; an exception to this will be seen in later equations where manufacturing is shown to have a higher growth rate in productivity that is statistically significant ${ }^{15}$.

In Table 3, we present the results of the analysis when the training variables are broken up into the general and specific categories. Focusing again on the training variables, the interesting finding to emerge is the significance of general training across all three specifications. Specific training, on the other hand, is not found to have a significant impact on productivity growth. It will be recalled that Black and Lynch (1996) also failed to find a significant effect for some types of training. However, they did find that off-the-job training had a positive and significant effect on productivity in manufacturing. Given that the bulk of off-the-job training is more likely to be general in nature, the broad thrust of their findings are consistent with ours.

\footnotetext{
${ }^{15}$ Huselid and Becker (1996) point out that the use of differenced equations in a panel data context can lead to difficulties of measurement error. In order to broaden the analysis, we also estimated equations in which we related the level of productivity in 1993 to the level of training in 1993. No significant
} 
In order to check the robustness of our models, we conducted sensitivity analyses in which we re-estimated the equations reported in Table 3 after dropping cases with outlying values. We excluded 4 firms which had reported training expenditures in excess of $12 \%$ of payroll, and 2 cases which had reported productivity gains in excess of 1 . In no case did these reestimations lead to any change in the pattern of results reported in Table 3 for the full viable sample.

While these results are consistent with our hypothesis that general training should have a greater impact on productivity growth than specific training, it is somewhat surprising that the latter is found to have no effect on productivity growth. It could be argued that companies are more likely to understate the amount of specific training undertaken by them if such training is given on a more informal basis than general training. If this is the case then we would expect the coefficient on specific training to suffer from upward bias; hence, this argument actually strengthens the finding of specific training having no effect in increasing productivity.

Another possible interpretation of the non-significant effect of specific training is that it represents a part of the normal operational expenses of a company, related perhaps to personnel turnover. It will be recalled from the discussion of the data above that although "trainees and apprentices" were excluded from the survey, incoming staff who did not fit the definition as set out in the instructions (see footnote 8) would have been included. Higher their productivity was particularly low, this lack of significance may not be surprising. 
spending on specific training may then have arisen in an environment of high staff turnover, in an effort to maintain productivity levels. In contrast, general training may have represented an additional investment above and beyond normal operating requirements and so enhanced company performance. As we do not have data on gross inflows and outflows of employees, we are not in a position to test if the provision of specific training is more highly correlated with staff turnover than general training. Looking at the correlation matrix in the Appendix however, we can see that the correlations between both general and specific training and net change in employment are not statistically different from zero. While this does not conclusively address the issue of whether the incidence of specific training is higher than that of general training where turnover is higher, is certainly reduces the likelihood of the argument being true.

This finding of a significant effect of general training prompted us to ask the question of whether general training was capturing the effects of other omitted variables which could have had effects on productivity growth over the 1993 to 1995 period. In particular, it seemed possible that firms that offer training that is general in nature may also employ a range of other policies which increase productivity. In addition, it could have been that large firms were more likely to be in a position to offer general training and to achieve productivity growth. In order to test for these possibilities we re-estimated the equations of Table 3 and included variables measuring the extent to which various corporate strategies and personnel polices had been introduced in the 1993 to 1995 period. We also included a dummy variable indicating whether a firm was large or not, where a large firm was taken to be one whose number of employees was above the median, i.e. 60 employees. In addition, we 
included a dummy variable that indicates if a firm under went some form of corporate restructuring over the period in question. Such re-structuring may have had a positive effect on productivity growth if new management was in some sense 'better' than the old; alternatively, a negative effect could be seen if a takeover or merger had a disruptive effect on the running of the enterprise. The results of this re-estimation are presented in Table 4.

Our concern that the general training variables were picking up the effects of other company policies is dismissed by the results in Table 4. The coefficients of the general training variables change little when this new set of variables are introduced. None of the new variables are significant. The finding that neither corporate innovation nor the introduction of new personnel policies have any discernible impact on productivity is in contrast to the findings of Huselid (1996). However, the lack of significance here may be related to a timing issue, in the sense that the period of observation may be too short for any positive effect of these policies to be felt. In addition, our measures are weak in the sense that they only indicate presence of the polices and do not capture information on, for example, number of employees covered. ${ }^{16}$

An additional line of inquiry into this general training effect was motivated in the following manner. We showed in Table 1 that the companies included in our survey increased both employment and capital assets by about 14\% over the 1993-1995 period. In each of the estimated models capital investment has a strong positive effect on productivity while the

\footnotetext{
${ }^{16}$ We also amalgamated the personnel and innovation scales into a single measure of corporate policy innovation (which generated a scale with Cronbach's alpha > .7) but the results from this were no more significant than from the effects of the two scales specified separately as reported in Table 4 .
} 
effect of increases in employment is negative. This led us to ask whether our findings of the positive effect of general training were concentrated among firms with an expansion strategy based on increased capital investment rather than employment growth. Thus, for example, if general training mostly took place in companies with high levels of capital investment, then the existence of a strong interaction might produce a positive effect of general training. To investigate this more formally we specified a series of interaction terms between general or specific training days with both investment and employment.

At this point, we also include a measure of the level of human capital in the enterprises in 1993. It can be argued that there is likely to be a complementarity between enterpriseprovided training and education, in the sense that training will be more effective when given to employees with higher initial levels of education. Once again, if general training is more likely to be given in firms where the employees are more highly educated, this association could be driving our results. In order to capture this, we include labour cost per employee as an explanatory variable, on the assumption that higher average labour costs reflect higher levels of human capital. We report the results in Table 5.

In model 10 the interaction between change in capital and general training is positive and significant; neither labour cost per employee nor the general training/change in employment are significant. The coefficient for general training is reduced, as is its significance, but it still remains significantly different from zero at the 5 percent confidence level. The impact of the investment is now seen to be statistically equal to zero; this indicates that the positive effect of investment is strongly related to accompanying general training. The payroll per employee 
variable has little impact on the model; we ran an additional model in which it was interacted with general training but again, the coefficient on the interaction was not significant. Hence, we are once again left with the conclusion that general training has a greater positive impact on productivity growth than specific training.

\section{Conclusion}

Our purpose in this paper has been to apply the familiar theoretical distinction between general and specific training to the empirical task of estimating the returns to in-company training. Using a firm-level dataset which includes information on the split between general and specific training across firms, we have tested for the relative effects on the two types of training on productivity growth. We find that although general training has a statistically positive effect on productivity growth, no such effect is observable for specific training. What is more, this positive effect of general training remains when we control for other workplace policies and corporate re-structuring, for firm size and existing level of human capital, and for interactions between general training and investment and employment growth.

A number of important implications flow from these results. As with the work of Sandra Black and Lisa Lynch, we have shown that different dimensions of training can have different impacts. While they, and others, looked at the distinction between on-the-job and off-thejob training, the results here show that the crucial distinction in training types when assessing impacts on productivity growth may be that of general versus specific. As we argued above, 
employees are not mechanical black-boxes into whom training is injected. Rather they are rational players who must choose the amount of energy they will devote to turning the training they receive into additions to their human capital. Training which increases an individual's wage with both the existing employer and potential employers provides greater incentives for effort than training which only increases wages with the existing employer. This view of the training process is true whether the employees pay for the training themselves, as predicted by Becker, or the employer pays. However, given recent work which casts a doubt on the narrow Becker prediction that employees pay all the cost of general training (Bishop and Kang, 1996, and Loewenstein and Spletzer, forthcoming) the findings in this paper generate an additional reason for re-examining the roles and incentives for both employers and employees in the provision of training. 


\section{References}

Bartel, Ann 1994. "Productivity Gains from the Implementation of Employee Training Programs.” Industrial Relations Vol. 33 pp 411-425.

Bishop, John H. and Suk Kang 1996. "Do Some Employers Share the Costs and Benefits of General Training?". Centre for Advanced Human Resource Studies, Working Paper 9619, Cornell University.

Black, Sandra and Lisa Lynch 1997. "How to Compete: The Impact of Workplace Practices and Information Technology on Productivity.", National Bureau of Economic Research Working Paper No. 6120, Cambridge, MA.

Black, Sandra and Lisa Lynch 1996. "Human Capital Investments and Productivity", American Economic Review. Vol. 86 No. 2 pp 263-267.

Becker, G. 1975. Human Capital (2nd Edition), New York: Columbia University Press.

Booth, Alison L. 1991. "Job-Related Formal Training: Who Receives it and What is it Worth?" Oxford Bulletin of Economics and Statistics Vol. 53 No. 3 pp281-294

Eurostat 1996. "Continuing Vocational Training in Enterprises - An Essential Part of Lifelong Learning." in Statistics in Focus: Population and Social Conditions, No. 7, pp. 1-4. Luxembourg: Eurostat. 
Fox, R. 1995. Company Training in Ireland, Dublin: FAS.

Holzer, Harry., Block, Richard., Cheatham, Marcus. and Knott, Jack 1993. “Are Training Subsidies for Firms Effective? The Michigan Experience., Industrial and Labour Relations Review Vol. 46 pp 625-636.

Huselid, Mark A. 1996. "The Impact of Human Resource Management Practices on Turnover, Productivity and Corporate Financial Performance." Academy of Management Journal Vol. 38. No. 3 pp 635-672.

Huselid, Mark A. and Brian E. Becker 1996. "Methodological Issues in Cross-Sectional and Panel Estimates of the Human Resource-Firm Performance Link." Industrial Relations, Vol. 35, No. 3, pp.400-422.

Ichniowski, Casey, Kathryn Shaw and Giovanna Prennushi 1995. "The Effects of Human Resource Management Practices on Productivity.” National Bureau of Economic Research Working Paper No. 5333, Cambridge, Massachusetts.

Loewenstein, Mark A. and James R. Spletzer Forthcoming “General and Specific Training: Evidence and Implications", Journal of Human Resources. 
Lynch, Lisa 1992. "Private-Sector Training and the Earnings of Young Workers." American Economic Review, Vol. 82 No. 1, pp299-312.

Lynch, Lisa and Sandra Black 1995. "Beyond the Incidence of Training: Evidence from a National Employers Survey." National Bureau of Economic Research Working Paper No. 5231, Cambridge, MA.

National Institute of Economic and Social Research 1990. Productivity, Education and Training: Britain and Other Countries Compared, N.I.E.S.R., London.

Schömann, Klaus. 1998. “Access to Life-Long Learning and Implications for Strategies of Organizational Learning in the European Union.” in H. Albach, M. Dierkes, A. Antal, and K. Vaillant (eds), Organisationslernen - Instituionelle und Kulturelle Dimensionen, Berlin: WZB.

Shapiro, Carl and Joseph Stiglitz 1984. "Unemployment Equilibrium as a Worker Discipline Device." American Economic Review Vol. 74. 
Table 1: Summary Statistics of Principal Variables $(\mathrm{N}=215)$

\begin{tabular}{lcccc}
\hline & Minimum & Maximum & Mean & Std. Deviation \\
\hline $\begin{array}{l}\text { Dependent variable: } \\
\text { Proportionate change in productivity }\end{array}$ & -0.746 & 1.359 & 0.034 & 0.321 \\
Training variables: & & & & \\
Trainees/Employees & 0.000 & 1.000 & 0.394 & 0.349 \\
General trainees & 0.000 & 1.000 & 0.194 & 0.239 \\
Specific trainees & 0.000 & 0.833 & 0.168 & 0.200 \\
Training days/Employees & 0.000 & 30.867 & 1.917 & 3.081 \\
General Training Days & 0.000 & 27.333 & 0.832 & 2.123 \\
Specific Training Days & 0.000 & 13.559 & 0.948 & 1.854 \\
Training expenditure/Payroll & 0.000 & 22.514 & 1.844 & 2.967 \\
General Training Expenditure & 0.000 & 11.289 & 0.835 & 1.614 \\
Specific Training Expenditure & 0.000 & 17.738 & 0.906 & 2.052 \\
Enterprise variables: & & & & \\
Investment & -0.790 & 2.495 & 0.148 & 0.377 \\
Change in employment & -0.700 & 2.273 & 0.128 & 0.329 \\
Personnel Policies & 0.000 & 3.000 & 0.405 & 0.791 \\
Corporate Innovation & 0.000 & 6.000 & 0.605 & 1.122 \\
Corporate Restructuring & 0.000 & 1.000 & 0.228 & 0.420 \\
Labour Cost/Employees in 1993 & 5,604 & 58,327 & 21,321 & 9,450 \\
Number of employees in 1993 & 10 & 5269 & 170.91 & 451.68 \\
Sector: & & & & \\
Catering & 0.000 & 1.000 & 0.074 & 0.263 \\
Construction & 0.000 & 1.000 & 0.051 & 0.221 \\
Distribution & 0.000 & 1.000 & 0.186 & 0.390 \\
Finance & 0.000 & 1.000 & 0.033 & 0.178 \\
Manufacturing & 0.000 & 1.000 & 0.581 & 0.494 \\
Transport & 0.000 & 1.000 & 0.019 & 0.135 \\
Other Sector & 0.000 & 1.000 & 0.056 & 0.230 \\
\hline
\end{tabular}

Note: The values for Payroll/Employees are in U.S.\$, based on an exchange rate of IR£ = U.S.\$1.50. 
Table 2: OLS Models of Proportionate Change in Labour Productivity, 1993-1995 $(\mathrm{N}=215)$

\begin{tabular}{|c|c|c|c|c|c|c|}
\hline \multirow[t]{3}{*}{ Equation } & \multicolumn{2}{|l|}{ (1) } & \multicolumn{2}{|l|}{ (2) } & \multicolumn{2}{|l|}{ (3) } \\
\hline & \multicolumn{2}{|c|}{$\begin{array}{l}\text { No. Of employees/ } \\
\text { Total Employment }\end{array}$} & \multicolumn{2}{|c|}{$\begin{array}{l}\text { Training Days/ } \\
\text { Total Employment }\end{array}$} & \multicolumn{2}{|c|}{$\begin{array}{c}\text { Training Expenditure/ } \\
\text { Payroll }\end{array}$} \\
\hline & Coefficient & $\mathrm{t}$-value & Coefficient & t-value & Coefficient & $\mathrm{t}$-value \\
\hline (Constant) & -0.038 & -0.458 & -0.015 & -0.194 & -0.004 & -0.055 \\
\hline Training & $0.099 *$ & 1.828 & $0.014 * *$ & 2.247 & 0.005 & 0.807 \\
\hline Ch in employment & $-0.558 * * *$ & -9.963 & $-0.556^{* * *}$ & -9.985 & $-0.560 * * *$ & -9.744 \\
\hline Investment & $0.222 * * *$ & 4.458 & $0.209 * * *$ & 4.177 & $0.215 * * *$ & 4.223 \\
\hline Catering & 0.024 & 0.233 & 0.016 & 0.155 & 0.013 & 0.127 \\
\hline Construction & 0.090 & 0.792 & 0.074 & 0.660 & 0.069 & 0.604 \\
\hline Distribution & 0.078 & 0.881 & 0.072 & 0.814 & 0.069 & 0.766 \\
\hline Finance & 0.046 & 0.364 & 0.074 & 0.588 & 0.068 & 0.539 \\
\hline Manu'ing & 0.087 & 1.074 & 0.076 & 0.948 & 0.087 & 1.064 \\
\hline Transport & -0.063 & -0.416 & -0.066 & -0.434 & -0.067 & -0.432 \\
\hline Adjusted $\mathrm{R}^{2}$ & & 0.329 & & 0.334 & & 0.32 \\
\hline
\end{tabular}

$\mathrm{p}<.10, * * \mathrm{p}<.05, * * * \mathrm{p}<.01$ 
Table 3: OLS Models of Proportionate Change in Labour Productivity, 1993-1995, Differentiating General and Specific Training $(\mathrm{N}=215)$

\begin{tabular}{|c|c|c|c|c|c|c|}
\hline \multirow[t]{3}{*}{ Equation } & \multicolumn{2}{|l|}{ (4) } & \multicolumn{2}{|l|}{ (5) } & \multicolumn{2}{|c|}{ (6) } \\
\hline & \multicolumn{2}{|c|}{$\begin{array}{l}\text { No. of Trainees/ } \\
\text { Total Employment }\end{array}$} & \multicolumn{2}{|c|}{$\begin{array}{l}\text { Training Days/ } \\
\text { Total Employment }\end{array}$} & \multicolumn{2}{|c|}{$\begin{array}{c}\text { Training Expenditure/ } \\
\text { Total Payroll }\end{array}$} \\
\hline & Coefficient & t-value & Coefficient & t-value & Coefficient & t-value \\
\hline (Constant) & -0.061 & -0.741 & -0.025 & -0.321 & -0.058 & -0.709 \\
\hline General Training & $0.239 * * *$ & 3.092 & $0.034 * * *$ & 4.083 & $0.035 * * *$ & 2.900 \\
\hline Spec Training & -0.119 & -1.260 & -0.016 & -1.623 & -0.016 & -1.654 \\
\hline Ch. in Employment & $-0.549 * * *$ & -9.924 & $-0.538 * * *$ & -9.900 & $-0.570 * * *$ & -10.105 \\
\hline Investment & $0.211 * * *$ & 4.289 & $0.212 * * *$ & 4.366 & $0.223 * * *$ & 4.474 \\
\hline Catering & 0.044 & 0.441 & 0.015 & 0.153 & 0.060 & 0.581 \\
\hline Construction & 0.125 & 1.106 & 0.088 & 0.812 & 0.122 & 1.081 \\
\hline Distribution & 0.102 & 1.163 & 0.077 & 0.896 & 0.111 & 1.248 \\
\hline Finance & 0.087 & 0.698 & 0.084 & 0.692 & 0.108 & 0.862 \\
\hline Manu'ing & 0.132 & 1.615 & 0.106 & 1.346 & $0.142^{*}$ & 1.724 \\
\hline Transport & -0.045 & -0.302 & -0.061 & -0.415 & -0.026 & -0.171 \\
\hline Adjusted R & 0.347 & & 0.37 & & 0.345 & \\
\hline
\end{tabular}

$\mathrm{p}<.10, * * \mathrm{p}<.05, * * * \mathrm{p}<.01$ 
Table 4: OLS Models of Proportionate Change in Labour Productivity, 1993-1995, Differentiating General and Specific Training and Controlling for Additional Enterprise Characteristics $(\mathrm{N}=215)$

\begin{tabular}{|c|c|c|c|c|c|c|}
\hline \multirow[t]{3}{*}{ Equation } & \multicolumn{2}{|l|}{ (7) } & \multicolumn{2}{|l|}{ (8) } & \multicolumn{2}{|c|}{ (9) } \\
\hline & \multicolumn{2}{|c|}{$\begin{array}{l}\text { No. of Trainees/ } \\
\text { Total Employment }\end{array}$} & \multicolumn{2}{|c|}{$\begin{array}{l}\text { Training Days/ } \\
\text { Total Employment }\end{array}$} & \multicolumn{2}{|c|}{$\begin{array}{c}\text { Training Expenditure/ } \\
\text { Total Payroll }\end{array}$} \\
\hline & Coefficient & t-value & Coefficient & t-value & Coefficient & t-value \\
\hline (Constant) & -0.047 & -0.569 & -0.009 & -0.109 & -0.038 & -0.461 \\
\hline General Training & $0.256 * * *$ & 3.292 & $0.033 * * *$ & 3.931 & 0.035 & $2.857 * * *$ \\
\hline Specific Training & -0.089 & -0.940 & -0.016 & -1.652 & -0.015 & -1.601 \\
\hline $\begin{array}{l}\text { Ch. in } \\
\text { Employment }\end{array}$ & $-0.567 * * *$ & -10.090 & $-0.551 * * *$ & -9.954 & -0.584 & $-10.180^{* * * *}$ \\
\hline Investment & $0.217 * * *$ & 4.350 & $0.219 * * *$ & 4.443 & 0.230 & $4.537 * * *$ \\
\hline Large Firm & -0.058 & -1.550 & -0.040 & -1.100 & -0.047 & -1.267 \\
\hline $\begin{array}{l}\text { Personnel } \\
\text { Policies }\end{array}$ & 0.016 & 0.662 & 0.010 & 0.415 & 0.008 & 0.335 \\
\hline $\begin{array}{l}\text { Corporate } \\
\text { Innovations }\end{array}$ & 0.007 & 0.396 & 0.011 & 0.641 & 0.011 & 0.640 \\
\hline $\begin{array}{l}\text { Corporate Re- } \\
\text { structuring }\end{array}$ & -0.069 & -1.525 & -0.062 & -1.373 & -0.065 & -1.430 \\
\hline Catering & 0.048 & 0.481 & 0.015 & 0.149 & 0.059 & 0.576 \\
\hline Construction & 0.133 & 1.186 & 0.090 & 0.820 & 0.123 & 1.091 \\
\hline Distribution & 0.116 & 1.299 & 0.086 & 0.987 & 0.120 & 1.330 \\
\hline Finance & 0.124 & 0.970 & 0.115 & 0.916 & 0.142 & 1.107 \\
\hline Manu'ing & $0.145^{*}$ & 1.765 & 0.115 & 1.444 & 0.151 & $1.821^{*}$ \\
\hline Transport & -0.024 & -0.159 & -0.045 & -0.301 & -0.008 & -0.055 \\
\hline Adjusted $\mathrm{R}^{2}$ & 0.352 & & 0.369 & & 0.345 & \\
\hline
\end{tabular}

$\mathrm{p}<.10, * * \mathrm{p}<.05, * * * \mathrm{p}<.01$ 
Table 5: OLS Models with the Addition of Interactions and an Average Labour Cost Control $(\mathrm{N}=215)$

\begin{tabular}{lcc}
\hline Equation & \multicolumn{2}{c}{$(10)$} \\
\hline & Coefficient & t-value \\
& & \\
(Constant) & -0.004 & -0.041 \\
General Training & $0.027 * *$ & 2.161 \\
Specific training & -0.015 & -1.569 \\
Ch. in Employment & $-0.649 * * *$ & -10.356 \\
Investment & 0.088 & 1.457 \\
Ch. in Employment $*$ General Training & 0.022 & 1.542 \\
Investment * General Training & $0.063 * *$ & 2.566 \\
Labour Cost/Employee & 0.001 & 0.240 \\
Catering & -0.007 & -0.073 \\
Construction & 0.056 & 0.525 \\
Distribution & 0.077 & 0.920 \\
Finance & 0.070 & 0.593 \\
Manufacturing & 0.098 & 1.288 \\
Transport & -0.076 & -0.530 \\
& & \\
Adjusted R & 0.416 & \\
\hline
\end{tabular}

Note: Only the results for the days of training per employee measure are reported here.

$\mathrm{p}<.10, * * \mathrm{p}<.05, * * * \mathrm{p}<.01$ 


\section{Appendix:}

Table A.1. Correlation Matrix

\begin{tabular}{|c|c|c|c|c|c|c|c|c|c|c|c|}
\hline & P.C. & T.D. & G.D. & S.D. & I. & Ch. E. & Pers. & Inn. & Reorg. & L.C../E. & Large \\
\hline Productivity Change & 1 & & & & & & & & & & \\
\hline Training Days/Employees & $0.14 * *$ & 1 & & & & & & & & & \\
\hline General Training Days & $0.24 * * *$ & $0.78 * * *$ & 1.000 & & & & & & & & \\
\hline Specific Training Days & -0.06 & $0.70 * * *$ & $0.149 * *$ & 1.000 & & & & & & & \\
\hline Investment & $0.16 * *$ & $0.13^{*}$ & 0.09 & 0.08 & 1.000 & & & & & & \\
\hline Ch. in employment & $-0.53 * * *$ & 0.05 & -0.01 & 0.09 & $0.15^{* *}$ & 1.000 & & & & & \\
\hline Personnel Policies & -0.04 & 0.04 & 0.03 & 0.02 & 0.02 & $0.14 * *$ & 1.000 & & & & \\
\hline Corporate Innovation & 0.01 & 0.06 & 0.01 & 0.07 & -0.05 & 0.04 & $0.33 * * *$ & 1.000 & & & \\
\hline Corporate Reorganisation & 0.00 & -0.06 & -0.05 & -0.02 & 0.10 & -0.08 & $0.17 * *$ & $0.20 * * *$ & 1.000 & & \\
\hline Labour Cost/Employees & 0.09 & 0.09 & 0.10 & 0.05 & $-0.17 * *$ & $-0.13 * *$ & -0.03 & $0.20 * * *$ & 0.10 & 1.000 & \\
\hline Large firm & -0.06 & 0.03 & -0.03 & 0.04 & -0.08 & -0.04 & 0.04 & 0.14 & 0.10 & $0.28 * * *$ & 1.000 \\
\hline
\end{tabular}

Note: Only the training days per employee measure is shown. 